\title{
Neurale netwerken en het symbolisch paradigma : bouwen aan de zesde generatie
}

Citation for published version (APA):

Hudson, P. (1991). Neurale netwerken en het symbolisch paradigma : bouwen aan de zesde generatie. Rijksuniversiteit Limburg. https://doi.org/10.26481/spe.19910614ph

Document status and date:

Published: 14/06/1991

DOI:

10.26481/spe.19910614ph

Document Version:

Publisher's PDF, also known as Version of record

\section{Please check the document version of this publication:}

- A submitted manuscript is the version of the article upon submission and before peer-review. There can be important differences between the submitted version and the official published version of record.

People interested in the research are advised to contact the author for the final version of the publication, or visit the DOI to the publisher's website.

- The final author version and the galley proof are versions of the publication after peer review.

- The final published version features the final layout of the paper including the volume, issue and page numbers.

Link to publication

\footnotetext{
General rights rights.

- You may freely distribute the URL identifying the publication in the public portal. please follow below link for the End User Agreement:

www.umlib.nl/taverne-license

Take down policy

If you believe that this document breaches copyright please contact us at:

repository@maastrichtuniversity.nl

providing details and we will investigate your claim.
}

Copyright and moral rights for the publications made accessible in the public portal are retained by the authors and/or other copyright owners and it is a condition of accessing publications that users recognise and abide by the legal requirements associated with these

- Users may download and print one copy of any publication from the public portal for the purpose of private study or research.

- You may not further distribute the material or use it for any profit-making activity or commercial gain

If the publication is distributed under the terms of Article $25 \mathrm{fa}$ of the Dutch Copyright Act, indicated by the "Taverne" license above, 


\section{NEURALE NETWERKEN EN HET SYMBOLISCH PARADIGMA: BOUWEN AAN DE ZESDE GENERATIE}

\section{Rede}

uitgesproken bij de aanvaarding van het ambt van bijzonder hoogleraar in de Taalkunde, in het bijzonder Neurale Netwerken en Psycholinguistische Processen $n_{n}$ vanwege de Stichting Wetenschappelijk Onderwijs Limburg aan de Faculteit der Algemene Wetenschappen van de Rijksuniversiteit Limburg op vrijdag 14 juni 1991

door

\section{Dr. P.T.W. Hudson}

Rijksuniversiteit Limburg, Maastricht, 1991 
Copyright 199/ by Patrick Hudson. Niets uit deze uitgawe mag worden verveelwoudigd en/of openbaar gemaakt, door middel van druk, fotocopie, microfilm of op welke andere wijze ook, zonder voorafgaande toestemming wan de auteur. 
Mijnheer de Rector Magnificus,

Dames in Heren verbonden aan de Rjuksuniwersitei Limburg;

en voors gü allen, die deze plechuigheid mer uw aunwerigheid hebt willen wereren,

Zeer gewaurdeerdeerde woehoonders!

\section{Inleiding}

Elke keer als u een krant openslaat, kunt u lezen over de meest uiteenlopende ontwikkelingen op het gebied van technologie. Koplopers in deze ontwikkelingen zjin de informatica en de computertechnologie. De hardware wordt steeds kleiner en sneller en de programma's worden steeds slimmer en af en toe zelfs gebruikersvriendelijker. In de nabije toekomst mogen wij werwachten dat de computer steeds meer aan het oog ontrokken zal worden, zoals dat nu al op de werkplek en thuis te bespeuren valit, wairbij u bijworbeeld aan wasmachines kunt denken. Zo mogen wij verwachten dat in plaats van dat er een toenemend aantal computers op bureaus zal werschijnen, de bureaus zelf in toenemende mate intelligenter zullen worden.

Veel van de taken waarvan wij graag zouden zien dat zij door deze getalskrakers uitgevoerd worden, zijn bijzonder complex. Dit zall niemand verbazen; als zij niet to ingewikkeld waren, dan was dit probleem reeds lang opgelost. Een gevolg van deze gedachtengang is de nog steeds voortdurende onwikkeling wan krachitger en snellere computers. De krachtigste computers ter wereld staan niet in Amerika of in Japan maar hier, in deze ruimte. Een ieder van $\mathrm{u}$ is in staat om prestaties te leveren die de mogelijkheden van de hedendaagse supercomputers ver te boven gaan. Vandaag wil ik u iets vertellen over de manier waarop wij een dezer dagen de computer van de toekornst kunnen bouwen. Ik zal u een aantal principes uitenzetten die al in ruime mate bekend zijin en die wij al gebruiken in het ontwerpproces. De computers van de toekomst zoals il mij die voorstel, zullen in belangrijke mate afwijken van de computers zoals wij die gewend zijn om in onze omgeving aan te treffen.

Een groot aantal van de taken waarvan wij willen dat ze door computers uitgevoerd gaan worden, weerspiegelen mogelijkheden en vaardigheden die wij bij mensen als vanzelfsprekend achten. Dit zijn taken waarin onze zeer flexibele zintuig-en begripsvermogens aangesproken worden. Het zijn onder andere deze vaardigheden die ons in staat stellen te communiceren met zo"n machine mits zo'n machine gebruikersvriendelijk genoeg is. Voordat wij het stadium bereiken waarin de computer een ware dienaar van de mens wordt, moeten wij precies weten hoe wij zulke vaardigheden kunnen implementeren. Een mogelijkheid on dit te bereiken is het vergaren van voldoende kennis over het menselijk brein, dat wij voor het gemak als computer beschouwen, en te kijken hoe dit zijn taken uitvoent. De op deze wijze verworven kennis kan mogelijkerwijs bijdragen tot het ontwerp en bouwen van toekomstig generaties computers. Maar het probleem is dat de menselijke of dierlijke hersenen een groots en zeer complex studie* object zijn. Het merendeel van onze kennis beperkt zich tot het gebied van de unatomie van de hersenem. Deze kennis kan vergaard worden door met het blote oog of een eenvoudige microsccop de hersenen te bestuderen. Ook kan men in het laboratorium onderzoeken hoe individuele hersencellen werken. Echte problemen ontstaan pas alls deze vergaarde kennis over individuele hersencomponenten gebruikt gaat worden om de werking van de hersenen als geheel te beschrijven. Het is belangrijk om inzicht te krijgen in de mate waarin onderzoek op anatornisch of neurofysiologisch niveau antwoord geeft op een vraag als: 'Hoe doet een brein wat een brein doet?' Alleen antwoord op deze vraag kan ons leren in of en in hoeverre de techniek van 'Reverse Engineering', een methode waarbij op basis van biologische beginselen een technisch ontwerp gemaakt wordt, haalbare en nuttige ideeên oplevert om met kennis van de hersenen een computer te ontwerpen. 
In 1943, bij de geboonte wan de modeme computer", publïeerden MeCulloch en Pints een artikel warin zij een eerste poging deden om de principes te beschrijwen over de manier warop de hersenen hun rekentechnische wonderen verrichten. De hersenen zijm, net als de rest vam ons lichaam, opgebouwd uit cellen. De mens heef gemiddeld ongeveer 10.000.000 miljoen hersencellen of neuronen die allemaal volgens thetzelfde primcipe lijhen werken. ledere cel is verbonden met vele andere cellen. Een cel 'vuurt' als hij voldoende prikkels wan andere cellen heeft ontvangen. Het wuren van die ene hersencel op zijn beurt prikkelit wer andere cellen die met zijn couput zujn verbonden. Netwerken onistaan door de hersencellen aan elkaar te knopen. McCuloch en Pitts gaven de aanzet tot een beter inzicht in de werking van zwlke netwerken. Volgens hen is het niet zozeer belangrijk om te wetten hoe cen enkele cel werkt, hoewel dit tot nu toe het belangrijkste onderwerp van onderzoek is geweest, mar hoe het geheel, het netwerk, in staat is om zoweel werschillende en complexe taken tilit te voeren.

De meeste van u zullen nog niet bekend zijn met kunstmatige neurale netwerken. 敢 zall datirom zo kort en eenvoudig mogelijk uitleggen wat het zijn en hoe ze werken. Daarnal zall $\mathrm{lk}$ u inleiden in wat wel als de grootste oitdaging woor dergelijke netwerken gezien word: het verwerken van Natururlijke Taal. Juist door het gebruik van taal onderscheidt de mens zich meer dan doot andere vaardigheden van andere levende wezens. Ons van nature alanwezige neumale netwerk is in staat om Natuurlijke Tall te verwerken; dat is wal uw netwerken op dit moment an het doen zijn. De kernvraag is: "Wat maakt het verwerken van natuurlijke taall zo moellijk voor kunstmatige netwerken?" De bijna vanzelisprekende neiging van wetenschappers om liever moelijke dan eenvoudige problemen te onderzoeken maakt dat de combinatie van taal en neurale netwerken een uldagend probleem vorint. Deze handschoen will ik graag opmemen.

Het gebied dat ik wil uitdiepen op zoek naar en oplossing woor het probleem van de verwerking van tatal, is dat van de architectutir. Architectutur is het plan op basis waarvan verschillende losse onderdelen samengevoegd worden. Van eenwoudige bakstenen en rotsblokken kunnen wij huizen, paleizen en kathetralen bouwen. De architecturir geeft de manier an waarop dergelijke bouwwerkem geconstrueerd moeten worden. Bij neurale netwerken verwijst de architectuur nasur de 'bedradingsschema's' en de manier waarop verschillende onderdlellen bepaalde taken kumnen witwoeren. Het zal blijken dat voor het uitwoeren door een computer van ingewikkelde en interessante taken ook weliswaar uit eenvoudige onderdelen samengestelde, ingewikkelde en interessante structuren nodig zijn. De hersenen hebben een rijke verscheidenheid atan structuren en een dergelijk complexe architectuir treft men ook aan by grote kunstmatige neurale netwerken. Dit leidt tot mija laatste punt: hoe kunnen wij de computer van de toekomst daadwerkelijk bouwen?

Een analyse van twee wat duistere onderwerpen, neurale netwerken en Natuurlijke Taal, kan ons helpen om te voorspellen hoe de volgende generatie computers eruit zal komen te zien. Deze volgende generatte zal veel sterker lijken op de 'rekenmachines' in deze zaal, uw thersens, dan welke tegenwoondig verkrijgbare machine dan ook. Het programma on deze vol gende generatie computers te onwerpen en bouwen heeft nu al de naam van de 'Zesde Generatie' gekregen. Het beoogt een vervolg te ziju op het Japanse 'Vijfde Generatie' programma om een kunstmatig intelligente computer te bouwen uit de tachriger jaren. Hoewel deze toekonstige ontwikkelingen soms op science-fiction-werhalen lijlen, hoop lk dat mijn rede $u$ wat meer inzicht in deze grote sprong in technologische vooruitgang anl brengen.

\section{Neurale Netwerken}

De eerste wrang die beamtwoord dient te worden is: "Wat zijin neurale netwerken?" "We beschouwen een enkele hersencel, een neuron, die wordt aangeslagen of geactiveerd als 
hij prikkels krijgt van andere hersencellen. Als een cel woldoende wordt geprikkeld, zal deze op zijn beurt ook 'vuren', daarmee een electro-chemische puls witzenden langs zijn axon een lange vezel die aansluitingen heeft met andere hersencellen. Deze aansluitingspunten worden synapsen genoemd en de ontvangende onderdelen wan de cell dendrieten. Zij ontlenen hun naam aan de boomachtig structuren die zichtbaar worden onder een micrscoop. Een hersencel heeft tussen 5.000 en 100.000 annsluitingen van andere cellen en maakt zelf vertinding met hondenden of zelf's duizenden andere cellen.

De natuurlijke cellen staan model voor de kunstmatige cellen, soms knopen genoemd om hun kunstmatige natuur te onderstrepen. Een knoop heeft een lijst van alle andere knopen waarmee hij verbonden is en dus voor zijn inputs zorgen. Daarnaast is er voor ellke aansluiting een gewicht aangegeven dat het belang aangeeft wan deze verbinding. Een hoog gewicht geeft aan dat een binnenkomende puls als belangrijk beschouwd moet worden. Deze gewichten kunnen positief of negatief zijn. Dit sluit asn bij het neurofysiologisch onderscheid tussen exciterende en inhiberende synapsen. Een binnenkomende puls met een positief gewicht verhoogl de kans dat de ontvanger zelf zal vuren of een grotere output activatie zal vertonen. Een puls met een negatief gewicht daarentegen verlaagr de kans op vuren. Het is belangrijk om op te merken dat cen lonoop en een cel uitsluitend zijn gedefinieerd in ternen van inputs en niet door kennis over waar de outputs naar toe gaan. Het is de input tive het gedrag bepaalt en niet de kennis over wat er met de output gebeurt. Het gedrag van teen knoop wordi niet beperkt of gestuurd door enig inzicht in de effecten die dit gedrag kan veroorzaken.

Voor de meeste interessante kunstmatige neurale netwerken geldt dat de functie die voor een knoop bepaalt of hij wel of niet zal vuren, wharbij de hoeveelheid binnengekomen en gewogen activatie in acht genomen is, een niet-lineaire is. Er is dus geen directe eenduidige relatie tussen input en output. Er zijn twee mogelijkheden. Ten eerste: als de gewogen som van de activaties een drempelwaarde te boven gaat, kan de knoop vuren. Dit is een "alles of niets" situatie. Ten tweede: het is ook mogelijk dat een verhoogde gewogen input een continue, verhoogde output geeft, zonder dat er eenvoudige relatie is tussen de output en de input. In beide gevallen heeft de niet-lineariteit tor gevolg dat bij lage gewogen input zelfs relatief grote veranderingen weinig invloed op de output hebben. Dit geldt ook voor de situatie waarbij de gewogen input de maximale waarde benaderd heeft. Daartussen zit een kritisch middengebied, waarin zelfs kleine veranderingen grote effecten kunnen hebben. Dit kan men opvatten als een versie van het drempelsysteem. Het "alles-of-niets'-systeem klapt van geen activatie om naar maximale activatie als een drempelwaarde overschneden wordt. Het meer variabele systeem vertoont in het kritische gebied een snel variërende activatie, terwijl het redelijk ongevoelig is voor variaties in input bij zeer lage of zeer hoge activatieniveaus. Dit betekent dat cen knoop. en waarschijnilijk ook een hersencel $l_{n}$ een beslissing neemt, gebaseerd op de totale som van zijn inputs. Dit beslispunt komt tot uiting in de output van de knoop.

In 1943 maakten McCulloch en Pitts ${ }^{2}$ modellen van zeer eenvoudig combinaties wan neuronen die wij nu zien en zelfs kopen als logische scheme's, poorten en schakelaars in alle digitale computers. Zij hebben ook de basis gelegd voor de wiskundige achtergronden wan rekenmachines: de automatatheorie (waarover straks meer). De volgende stap werd genomen door de Canadese psycholoog Donald Hebb. Hebb3 toonde aan hoe een hersencel zijn output-gedrag zou kunnen aanpassen aan zijn input, met andere woorden, kunnen leren van zijn ervaringen. Als een cel gevuurd heef, zouden de inputs die positief hebben bijgedragen aan het vuren 'beloond' kunnen worden unet een kleine verhoging van de gewichten, terwijl de anderen gestraft zouden kunnen worden met teen vermindering van de gewichten. Een knoop kan dus leren door meer gevoelig te worden voor nuttige input en minder gevoelig voor allle andere prikkels. Hebb kwami ook met het idee dat informatie bewaard kon blijven in kleine groepen van zenuwcellen die een soort van echoènde kring zouden kunnen vormen. Hij noemde de structuren Cell Assemblies. Met deze Cell Assemblies heeft Hebb de aandacht verplaatst naar gedetailleerde kleine-schalige structuren. Hij week hiermee af van het tol dan toe gangbare model van Karl Lashley, die de werking van de hersenen verklaarde met behulp 
van hel begrip 'Mass Action', warbij de hersenen werden woorgesteld als een ongedifferentieerde en ongespecialiseerde massa ${ }^{4}$

\section{Het Perceptron en de Neergang van het Newrale Netwerk.}

Met het werk van mensen zoals McCulloch, Pits en Hebb werd de interesse voor meurale netwerken, hun mogelijkheden om ondaniks schade te blijven werken, en hun potentieel voor zelforganisatie aanxienlijk aangewakkerd. Het onderzoek dat in de jaren viffig plaatsvond, bestond echter uit nogal ongestructureerde demonstraties van voomamelijk Lleinuschalige problematiek. Met behulp van deze rieuw verworven inzichten construeende Rosenblatt cen netwerk dat hij 'Perceptron' noemdes. Perceptrons waren betrekkelijk eenvoudige structuren die in stal waren lets te leren. Deze simpele structuren kristalliseerden zich uiteindelijk wit in een twee-lagenmodel. In dit model is de eerste laag werbonden met de input kant. Een voorbeeld wan input kan een handgesehreven letter zijn. De output van de eerste laag dient op zijn beurt weer als input voor de tweede laag, waar beslissingen genomen worden. Er kunnen bijvoorbeeld 26 knopen zijn die elk geloppeld zijn aan een letter in het alfabet. Voor een perceptron is uitsluitend de aard wan de eerste input van belang en niet zozeer de preciese samenstelling. Aangezien het niet altijd duidelijk is wat er nu eigenlijk berekend moet worden, is het zelflerende karakier wan het systeem erg aantrekkelijk. Dit betekent dai hell systeem het vermogen heeft om zich op zodanige wijze te organiseren dat het op optimale wijze met de gegevens om kan gaan die het aangeboden krijgt. Een andere eigenschap van een dergelijk systeem is dat met veel onderling verbonden elementen ook ruizige, van veel storingen voorziene, input goed en snel onderscheiden en verwerkt lkan worden. Indien enkele knopen aan de input zijde ontbreken, zall dit maar weinig effect hebben op het al niet herkennen van relevante informatie.

Deze eigenschappen, het vermogen om te leren en de zelf-organisatie en zekere tolerantie voor fouten zijn zeer aantrekkelijk. Digitale computers zijn helemaal niet verdraagzaam en hebben nogal wat software nodig om uberhaupt te werken, laat staan te werken onder ruizige omstandigheden. Het zijn juist deze omstandigheden die we in het dagelijks leven, buiten het laboratorium, aantreffen. Het was deze tolerantie die onderzoekers in de jaren 50 ertoe aanzeltte om neurale netwerken daadwerkelijk te bouwen. Uiteindelijk vereisen de meeste elektronische en digitale computers een hoge mate wan nauwkeurigheid. Een storing velt een computer in zijn geheel en hij is niet meer in staat om goed te functioneren. De machines die witeindelijk gebouwd werden door de neurale netwerk onderzoekers zaten zeer vemuftig in ellkat, al waren ze weinig praktisch. Ze waren in staat om ondanks slecht soldeerwerk en zelfs loszittende draden nog steeds hun werk te doen.

Een van de onderzoekers was de wiskundige Marwin Minsky ${ }^{6}$. Samen met zjjn collega Seymour Papert was hij tot de owertuiging gekomen dat het werk tot nu toe, hoewel erg leuk om to doen, in wezen op drijlzand was gebouwd?. De apparatuur bleek bij complexiere voorbeelden ntet goed te functioneren, zelfs indien er meer appariatuir bijgehaald werd. Met andere woonden: sommige problemen konden ze helemal niet aan, en andere onvoldoende. Minsky en Papert ondernamen de taalk de Perceptrons van een wiskundige basis te voorzien. Terwijl zij dit deden ontdekten zij wat de Perceptrons in hun tweelagige variant eigenlijle deden. Zij ontdekten dat deze uitsluitend een onderscheid konden maken en iets leren van zogenaamde 'lineaür onderscheidbare' groepen patronen, de zogenaamde lagere ordle problematiek. De effectiviteit van het beslisgedeelte werd uitsluitend bepaald door de mate warin lineair onderscheidbare groepen wan stimuluspatronen gemakt konden worden. ${ }^{8}$

Hoewel Perceptrons zelflerend zijn, wait op zich een belangrijk voordeel was boven systemen waurbij de precieze onderscheidingsregels gedefinieerd moesten worden, was 
het gebruik van Perceptrons toch geen panece. Inderdand konden meer complexe Perceptrons gecompliceerdere problemen aan, malu de crix van hur argumenten was, dat de groei van het netweit alrijd groter moest zijn dan de toenemde grootic van de problemen waar ze op los gelaten konden worden?. Het resultad van Minsky en Paperts werk was een vrijwel onmiddellijke ineenstorting wan een hele tak van wetenschap. De bronnen van fondsen in de Verenigde Sitaten droogden op en de onderzoktkers richten zich weer op nieuwe terreinen teneinde om nieuwe brownen an te boren. In een latere versite van de introductie en epiloog van hun boek beargumenteenden Minsky cn Papert dai het toch tijd was voor een snoeiting in dit veld en dat wij niet zo zeer een oorzak waren ma:ar meer een gevolg van de tijdgeest. Heel interessant en toch vaak over het hoofd gezien of verkeerd begrepen is dlat de auteurs van dit boek toch optimistisch bleven over neunale netwerken. Zij spraken de hoop uit dat deze op een solidere onderbouwde grondsing geplaalst rouden worden.

\section{Het Symbolisch Paradigma}

In de jaren vijftig ontstond er een geheel nieuwe benadering om inzicht te krijgen in de wijze waarop gecompliceerde intellectuele functies uitgevoerd konden wordien. Voortbouwend op ideeen van mensen als. Turing en inzichten die al een wat langere historie in de filosofie hebben, ontstond de wetenschap vam de Kunstmatige Intelligentie. In de heersende stroming werd de werking van processen uitgedrukt in de bewerking wan symbolen. Deze processen konden een gedrag vertonen dat we gewoonlijk alls intelligent of intelligentie vereisend bestempelen. Minsky, de belangrijke neurale-netwerkonderzoeker, was ook een wan de grondleggers van deze nieuwe symbolische benadering. Dit houdt in, dat er afzonderlijke symbolen zijn die voorwerpen, of relaties tussen voorwerpen, in een machine representeren en daarop bewerkingen kunnen loslaten die eenduidig gedefinieerd zijn en tot zichtbare resultaten leiden. Dit is een duidelijk

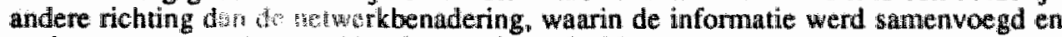

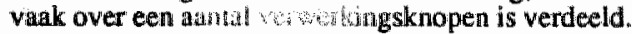

De ontwikkeling van de artificièle intelligentie ging in het begin stapvoets en had veel minder te verduren van de opgeblazen en overspannen verwachtingen die samen met de publikatie van Minsky en Papert"s werk in 1969 de corzaak geweest waren van het abrupt beeindigen van het onderzoek nasur neurale netwerken. Het onderzoek richtre zich voornamelijk op het analyseren cn mabootsen van specifiek menselijke vaardigheden, zoals visuele perceptie en Natuurlijke Taal. Men getroostte zich veel inspanning bij het onderzoek naar het vraagstuk hoe kennis gerepresenteerd dient te worden en hoe dan met behulp van die kennis logische gevolgurekkingen gemaakt kunnen worden. Deze ketnnis werd heel expliciet weergegeven en de systemen voor de logische gevolgtrekkingen werden meestal gericht op het winden van algemene methoden, ongeacht het onderwerp, voor het bereiken van de specifieke doeleinden van dat onderzoeksonderwerp. De symbolische benadering leidde onder andere tot de ontwikkeling van het expert-systeem. Dit is een computer-programma dat een menselijke expert nabootst en zijn of hutur kennis weergeeft meestal in de vorm van expliciete regels.

Karakteristick voor de symbolische benadering is exn inwloedrijk programma van Newell, Shaw en Simons: de Gieneral Problem Siolver $10.2 \mathrm{Jj}$ brachten als eersten het idee naar voren dat het oplossen van een probleem in de ruimste zin gezien kan worden als een serie overgangen van een begintoestand nar de gewenste eindioestand. Voorbeelden zijn spelen zoals dammen, schaken en go, waarin iedere tussenliggende stand op het bord gezien kan worden als een toestand. Het probleem wordt vervolgens in een zodanige vorm gegoten dat er gezocht wordt naar de beste weg door het woud wan mogelijke varianten om het gewenste doel te bereiken. Interessant worden problemen pas voor de Kunstmatige Intelligentie als deze niet langer met brute kracht opgelost kunnen worden. Heuristieken, effectieve wuistregels, kumnen worden toegepast om de complexiteil en omvang van de zoekruimte te verninderen. Wat deze benadering echt onderscheidt van 
de newwerkberiadering is het gegeven dal de toestanden en overgangen em zelfs de heuristicken zelf ook onderwerpen zijn warmee en waarover berekeningen aitgevoerd. kunnen worden. Kunstmalige intelligentie kan opgewat worden in termen van Newell's Physical Symbol System hypothese, waanin intelligentie gezien wordt als en functie van het systeem, ongeacht de wratag hoe dat systeem geilmplementeerd is ${ }^{11}$. In zall op het symbolisch paradigma later terugkomen.

\section{Het Logogen en de opkomst wan PDP}

Slechts een klein aartal onderzokers zette het werk in de neuralle netwerk traditie voort. Binnen de experimentele psychologie bleef de meer algemene notie wan een systeem dat aanwijzingen kan combineren, door de Engelsman John Morton 'Logogen' genoemd "2, een vruchtbare bodem bieden om gedrag te verklaren als het herkennen van woorden onder moeilijke ornstandigheden of wanneer betekenis een rol speeli waardoor woorden gemakkelijker te herkennen zijn. In San Diego begon een groep onder lleiding wan Don Norman ${ }^{15}$ en met de psycholoog David Rumelhart gedetallieerde modellen voor woordherkenning te maken die zeer suecesvol waren in het woorspellen en verklaren van antwoorden op vragen als: "Hoe zie je een woord dat mar een fractie wan een seconde zichtbaar is?" en: "Wal voor fouten mak je dan?' Rumelhart en McClelland" ontwikkelden dit model verder en vormden de PDP onderzoeksgroep 15 . PDP staat voor Parallel Distributed Processing en geeft al aan dat hun interesse ligt in het afwijken van het pad waarop zeer nauwkeurig omschreven modellen van mentale processen worden gebruikt waarin de ant woorden op bovenstaande vragen eigenlijk al opgesloten liggen in de manier warop de modellen in eerste instantie waren opgesteld.

PDP bracht een zeer succesvolle architectuur en lerend algoritme voort. Ik breng bij u weer in gedachte de 'Perceptrons mer hun twee lagen, die door Minsky en Papert's werk. de kwalificatie van "oninteressant" hadden gekregen. De nieuwe ontwikkeling behelsde het inwoegen van een derde, tussenliggende, laag, de 'verbougen' laag genoemd. Bij het leerproces wordt gebruilk gemakt van het verschil tussen de gewenste en werkelijke eindtoestand. Dat werschill wordt weet teruggewoerd in het netwerk waarbij de gewichten worden aangepast, eerst tussen de verborgen laag en de uitvoer laag en dan wan de werborgen laag naar de inwoer laag. Deze techniek, hoewel vrij tragg "werkt goed en heeft geen last wan de beperking dat er alleen lineair onderscheidbare patronen onderscheiden kunnen worden. Daardoor is dit zogenaamde Back Propagation of Errors ${ }^{16}$, kortweg Back-Prop, zeer populair geworden.

In de jaren zeventig en tachtig werden ook andere disciplines daa psychologie geinteresseerd in deze benadering. De Fin Tuevo Kohonen onderzocht het vermogen van netwerken om informatie te omthouden 17 . Voorbeelden zijn het reconstrueren en herkennen van gezichten van onduidelijke foto's of foto's waarvan slechts enkele onderdelen zichtbarar zijn. De natuurkundige Hopfield en zij collega Tank18 ontwikkelde een zeer eenvoudig netwerk om zeer moeilijke problemen zoals het klassieke handelsreizigersprobleem op te lossen. In dit probleem is er een handelsreiziger die een antal steden moet bezoken in de kortst mogelijke tijd of door het minste aantal killometers te rijden. Een woorwarde hierbij is, dat hij elke stad slechts eenmaal mag bezoeken. Een kenmerk wain de Hopheld-Tank ${ }^{19}$ netwerken is dat ledere knoop is verbonden mell alle andere knopen: totale interverbondenheid. In een toepassing van het handelsreizigersproblem representeren de knopen de steden en positie in de rondreis, de gewichten representeren de afstanden tussen de steden en zorgen ervoor dat er vanuit ellke positie slechts eén volgende stad gekozen kan worden. De netwerken van Kohonen zijin twee-dimensionaal, masur hebben niet de eigenschap van totale interverbondenheid: iedere knoop is slechts verbonden met de relatief dichtbujzignde buren. 


\section{Natuurlithe Taal}

Gelijktijdig met het ter ziele gaan wan de neurale netwerken aan het eind van de jaren zestig kwam de alternatiewe symbolische benadering op. Het verwerken wan taal, bestaand uit woonden en hun betekenis, is mischien wel de meest symbolische activiteit die er is. Het probleem met het verwerken wan taal is hoe we, bijvoorbeeld in het geval van spraak, aan klanken betekenis kunnen hechten. Woorden hebben betekenissen, anders gezegd: woorden worden gerepresenteerd door symbolen in het hoofd van zowel de spreker als de luisteraar. Veel onderzoek wordt gedaan naar de vraag thoe we fysische prikkels, de geluidsgolf, als woord kunnen interpreteren. Het woord lijkt het meest belangrijke deel van taal. Dit gaat" zeker op wanneer we ons een nieuwe taal eigen proberen te maken; het zijn de woorden die we moeten leren, zeker wan talen die weinig of niets gemeen hebben met de taal of talen die we al kennen.

Woorden op zichzelf zijn nog geen taal. Chimpansees en gorilla's kunnen ook woorden gebruiken, met hulp van gebarentaal of het plaatsen van verschillende vormen op een bord. $\mathrm{Zij}$ missen echter de essentiele van verschillende dingen. We kunnen oneindig veel combinaties wan woorden maken door woorden in zinswerband bij elkaar te zetten. "Man bijt hond' is nieuws, 'Hond bijt man' niet, behalve dan natuurlijk voor de man die gebeten wordt. De precieze wijze waarop we woorden kunnen samenvoegen is vastgelegd in de grammatica van een taal, wasronder de syntaxis of zinsbouw. Het lijkt erop dat onze meest nabije biologische familie op het niveau van de syntaxis heel ver van ons af staat. De manier wasrop zij zich kuwnen uiten blijf beperkt, hoe verbazingwekkend goed ze ook kunnen zijn in her overbrengen van een bepaalde boodschap. In beschouwingen over eigenschappen van de menselijke taal, waaraan Noam Chomsky belangrijke nieuwe impulsen heeft gegeven 20 . wordt erkend dat wat voor systeem ook in staat moge zijn om natuurlijke taal te verwerken, het in staat moet zijn om overweg te kunnen met het gegeven dat er een oneindig aantal mogelijke zinnen is. Niet dat iemand trouwens meer dan een heel klein gedeelte van het total aan mogelijke zinnen ooil zal horen of zeggen. Een wezenlijk probleem is, dat er in principe geen manier is om de bovengrens van de llengte of complexiteit van een zin vast te leggen. Praknische of 'uitwoeringstechnische' redemem kunnen beperkingen opleggen met betrekking tot wat wij ook werkelijk kunnen zeggen, maar de grenzen zijn rekbaar. Een op wetenschappelijke gronden beargumenteerde limiet zou ons in staat stellen om een duidelijke grens te bepalen voor eigenschappen als zinslengte of grammaticale complexiteit. Wat we gevonden hebben, is echter dat de grenzen rekbaar zijn en zelfs door oefening wat verlegd kunnen worden.

Er is nogal wat verwarring over de vraag of taal beschreven moet worden in termen van communicatie, wat uiteindelijk de belangrijkste functie is, of als een bijzonder en uniek formeel systeem. De formele benadering, waartoe de aanzet gegeven werd door Chomskyaanse grammaticalisten, plaatst sterke nadruk op de soort symbolen en de eigenschappen van de bewerkingssystemen die deze symbolen kunnen gebruiken. De in overwegende mate functionele benadering plaatst taal voornamelijk in zijn ongeving. Feil b.lijft, dat het 'oneindigheidprobleem' niet opgelost is en de verbazingwekkende beperking van de 'grote apen', ondanks hun relatief grote commuäicatieve vaardigheden, maakt dit nog eens duidelijk. Een verklaring voor dit probleem is tot nut toe nog niet gegeven. Wat we willen, is niet alleen eenvoudigweg een bepaald fenomeen zoals natuurlijke taal, beschrijven, we willen het kunnen verklaren. We willen in staal zijn asan te duiden waaron het is zoals het is en niet anders. Waarom, bijvoorbeeld, hebben talen zelfstandige nuamwoorden en werkwoorden? Waarom kunnen we het maar over cen ding te gelijk hebben en waarom zijn sommige grammaticale regels zo beperkt in hun vorm? We kunnen deze fenomenen verklaren door verwijzing naar de algemene opvatting van tall als communicatie, en het probleem te leggen bij de beperking van het informatieverwerkend systeem van het individu, dan wel het probleem toe te schrijven aan beperkingen die inherent zijn aan die taal. 
Chomsky hechte veel waarde an het kunnen verthanen: hij onderscheidde grammatica's natar de mate wainim ze verklarende of beschrijvende eigenschappen hadden. Toch blift er het feit, dat veel van de verkilaringen van grammaticale verschijnselen door linguisten gebaseerd zijn op system-eigen factoren. Er ziljn ent enge verwijzingen naair eigenschappen wan hel grammaticale systeem zelf, maar zelden nar externe factoren. Wannetr al verwezen wordt naar factoren, zoals de psychologische voorkeur voor de volgorde vain onderdelten wan woorden of zinnen, dlan lijken deze factoren net zo goed voor apen wan toepassing te zijn als voor mensen. Er us dus geen externe verklaring woor het antwoord op de vraag waarom mensen juist deze soort taal hebben. In het bijzonder zijn er weinig verklaringen woor de vraag waarom we de regels hebben die we hebben. Algemene rekensystemen, zoals die gebruik: worden in de Kunstmatige Intelligentie, stellen niet zulke beperkingen, en we schijnen te kunnen functioneren met een hele beperkte set. Het is net alsof onze taalcomputer er een is met een hele beperkte machinetaal.

Chomsky serste beschrijwing wan de grammatica voor menselijke taal was gewat in een formallisme, de "Transfommational Generative Grammar" genaamd. Deze grammatica stelt ons in swat om twee zo op het eerste gezicht verschillende zinnen 'John zag Mary' en "Mary werd gezien door John" tot een onderliggende representatie teruggebracht kunnen worden, zodat de betekenis weer in overeenstemming is met wat wij weten, namelijk dat het in wezen dezelfde zin is. De transformationele grammatica bleek veel te krachig, hij kon werkellik alles verklaren. Sinds men zich hiervan bewust werd, hebben onderzoekers van tal., inclusief Chornsky, getracht een framework te bouwen met hell zwakst mogelijke systeem dat toch aan de gestelde woorwarden voldoet. Een contextvrije grammatica heeft juist dit minimaal noodzakelijke wermogen en is toch in staat om een oneindig antal zinnen te genereren.

Het is trouwens niet alleen het verwerken van naturlijke taal dat van ons een minimale hoeveelheid verwerkingskracht eist. Een nog veel moeilijker en duister probleem is de manier waarop wij een Naturrlijke Taal kunnen leren. De studenten van Natuurligke Taal, kleine kinderen, worden geplaatst in een omgeving waar de totale hoeveelheid aangeboden materiaal op basis warvan zij moeten leren zeer beperkt is. Dit aangeboden materiaal zit vaak ook vol fouten of is slordig opgebouwd en wondt zeker niet aangeleerd volgens een strikt en goed omschreven leerplan. Toch kunnen zij hun moedertaal opmerkelijk snel begrijpen en spreken. Voor een kind is de ene tral niet moeilijker aan te leren dan een andere. Dil verschijjnsel wordt vaak beschreven alls de noodzaak van een kind om meer te gebruiken dan alleen dat wat wordt aangeboden. De vragen die dan beantwoord moeten worden, zijn: "Hoe doet een kind dit?" "Wat moet een kind al aam kennis over taal hebben om een taal te leren? "ls thet mogelijk om een taal te leren op basis van een soort algemeen vermogen om regelmatigheden in de wereld op te merken?" Het antwoond lijkt te zijn dat er een aanzienlijke hoeveelheid aangeboren structuren zijn, klaar om aan taal blootgesteld te worden. Het is daarentegen cok zo, dat deze aangebonen structurur er nogal abstract uitziet. Misschien kan ik dit iets duidelijker maken met behulp van anologie: de werking wan het genetisch thaterial DNA. Indien er aan cen aantal noodzakelijthe en woldoende voorwaten voldaan wordt tijdens de ontwikkeling van het embryo is kan DNA eenheden te ontwikkelen van eern onwoorsteibare complexiteit, tot en met de menselijke hersenen, klaar om tal te ontvangen en te lenen.

Deze eerste aangeboren structutar, die noodzakelijk lijkt woor taalverwerving, geeft geen volledige verklaring voor dit probleem. Het kind moet zich ontwikkelen vanuit een bevruchte cel, in cen ongeving die zich daartoe leent. DNA is noodzakelijk om een mens

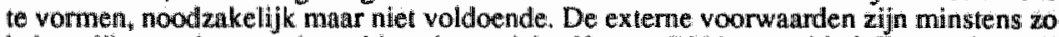
belangrijk en ook weer niet voldoende op zichzelf: geen DNA, geen kind. Zo gaat het ook met taduerwerving. Het onderzoek dat bedoeld was om de angeboren structuuropwating af te zwakken, in een poging deze vereiste total uit te roeien, toonde echter op overtuigende wijze an hoe connplex en subtiel de ongeving moet zijn om de aamgeboren vaardigheden tot bloei te brengen. Het legt daamaast nog eens de nadruk op het feit dat de 
amgeboren stucturur net zo abstract en moellik te relateren is an het eindprodukt alls de DNA-reeks zelf.

Deze aangeboren structuren vereisen cen hoge mate wan mogelijkheid atot aampassing. Voor de puberteit kunnen de meeste kinderen meer dan efen taal oppakken en zelfs zo goed spreken, dat ze nauwelijks te onderscheiden aijn van diegenen wier moedertal het is. Na een bepaalde kritische leeftijd wond dit echter een stuk moellyker, tets waar ik telf het llevend bewijs van ben. Wat onderzocht noet wonden ${ }_{m}$ is de vraag wal voor apparat in staat is om Natuurlijke Taal te leren. Net als in het voorgaande probleem zoeken we niet naar het meest maar naar het minst larachuge apparat dat dit kan. Er is een minimule hoeveelheid vermogen nodig om een taal te lenen die complexer is dan een Reguliere taal. Voor dit soort taal is bewezen dat het voldoende is om een zogenarnde 'Finute State Automaton' te implementeren. Maar Natuwrijke Talen zijn geen reguliene talen: ze zijn ingewikkelder. Orm Nahuurlike Taal te leren moet het minimale vernogen dan ook groter zijn dan van een "Finite State Automaton" We moeten de eigenschap van de oneindigheid van het aantal mogelijke zimnen binnen ons bereik zien te krijgen. De eerste kandidaat voor een systeem dat meer vermogen heeft dan een 'Finite State Automaton' is een ${ }^{8}$ Push Down Automaton", een stapelatomat.

\section{Alutomata Theorie}

Het is niet mijn bedoeling om hier diep in te gaan op een voor de meeste mensen wat exotisch gebied, de 'Automata "Theory". "Automata Theory', de studie varn wat rekensy stemen allemaal wel en niet kunnen, loopt dwars door de onwikkeling van zowel neurale netwerken, wan McCulloch en Pitts, als van "Taal, zoalls bedoeld door Chomsky. De krachtigste systemen kunnen beschreven worden als 'machines", zoals de "Ceneral Turing Machines: Turing was een Engelse wiskundige en was een wan de vaders van de modeme computers, zowel van de apparaten zelf (met zijn geheime werk aan Enigma) als van de programmatuur. Onder deze "Gemeral Turing Machines" zijn een hele range van steeds zwakkere machines of "automata". De zwakste is de "Finite State Astomaton' en de daaropvolgende is de "Push Down Automaton". Tussen de 'General Turing Machines' en de 'Push Down Automaton' zit nog een tussenvorm: de 'Linear Bounded Automaton." Het belangrijkste verschil tussen een "Finite State Automaton" en een "Push Down Automaton' is dat eerstgenoemde geen apart geheugen heeft waar het systeem op terug kan vallen. Alle berekeningen moeten weergegeven worden in een serie van precies gedefimieterde acties. Een 'Push Down Automaton" daarentegen kan tussenliggendle uitkomsten opslaan in een stapelgeheugen dat alleen toegankelijk is via het bovenste opgeslagen gegeven. Een stapelgeheugen is als een stapel van schijven. Om bij de vijfde schijf te komen, moeten we eerst de bovenste vier afnemen, die dan ook geen deel meer uitmaken van de stapel. Zo'n beperkt geheugen is een voldoende voorwatudle voor het vermogen om een oneindig aantal zinnen te kunnen genereten. Een 'Linear Bounded Automaton' heeft meer vermogen dun een 'Push Down Automaton" omdat eerstgenoemde systeem elk afzonderlijk geheugen kan gebruiken zonder de beperking dat opslag en toegang tot het geheugen alleen mogelijk zijn via het bovenste element van het stapelgeheugen.

Vanuit een wetenschappelijk gezichtspunt willen we verschijnselen kunnen verklaren om ze te kunnen begrijpen en voorspellen. Her kan tegen de incuitie ingaian mat de beste verklaringen zijn die verklaringen die de minst krachtige apparaten nodig hebben om de gevraagde verschijnselen te vertonen. Een werklaring die gebruik maaki wan een 'Push Down Automaton heeft altigl de voorkeur boven een verklawing die gebnilik makil van een 'Linear Bounded Automaton'. Op zijn beurt is een verklaring die gebruil makt wan een 'Linear Bounded Automaton' weer te preferen boven een werklaring die gebruik maakt wan een "Generall Turing Machine". Als bij Natuarlijke Taal de syniaxis in beschouwing wiordt genomen, is een 'Push Down Automaton' de minimale veresste. Het probleem is nu, dat alle neurale netwerken die ik eerder noemde slechts 'Finite State Automaton" zijn. 
Pogingen on netwerken te bouwen die miet-triviale grammaticale constructies kunnen

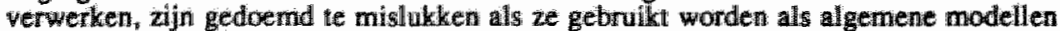
voor Natwurlifhe Taal. Die voorbeelden warin een beperkt geheugen gebrukt is, zoals. bij netwerken met terugkoppeling, kunien ook niet dienen als algemene madellen, zelfs all zin ze redelijk succesvol bij het uitwoeren wan beperkte en tamelijk ingewikkelde praktitsche roepassingen. Alle pogingen om de prestaties te verbeteren wijzen in de richting van wat essentieel lijki voor het verwerliken voor allerlei soorten van symbolen, namelijk het vermogen om informatie in en geheugen vast te houden. Met andere woorden: Informatie om over na te denken of ower te pratem. Een "Finite State Automatont handeli onverbiddelije in cen vaste volgonde: wan de ene stap mair de volgende. Keuzes tussen alternatieve stappen worden witsluitend gemalkt op basis van toevall. Een "Pusth Down Awomaton' daarentegen kan informatie onithouden en daar later gebruik wain maken. Het gedrag van zo'n automat wordt bepaald door wat er in het geheugen zit. Dit is de kern wan de symbolische benadering. We hebhen immers af zonderlijke elementen of representaties waarnaar het apparaat kan verwijzen en er zijn regels die het gedrag bepalen in temen van deze lementen of representaties.

Geen wan de netwerken die ik eerder genoemd heb, heeft het vermogen om dingen te onthouden, tenminste van de soont die hiervoor nodig is. Ze kunnen wel degelijk zaken onthouden, maar ze kunnen wiet zowel het onthouden van een erwaring weergeven als onafhankelijk daarwain onthouden dat er $20^{\prime \prime} \mathrm{n}$ geheugen is waar die ervaring in ligt opgeslagen. In netwerken worden al hun ervaringen samengebracht in variaties in gewichten en dat betekent dat de volgorde waarin de ervaringen waren opgedaan en de bijzonderheden van die ervaringen slechts in geringe mate worden weergegeven. Deze mogelijke problemen zijn in cen andere vorm all eens gemaakt door de filosoof Fodor 21 Al deze bezwaren zijn uitsluitend van toepassing op twee-dimensionale of meerlagige netwerken. In een ander artikel2 heb ik vastgesteld, dat dergelijke structuren op hun best nulde- of eerste-orde benaderingen zijn wan de structuur van echte hersenen. Benaderingen van de nulde-orde zijn netwerken die volledig of bujna volledig onderling verbonden zijn. Ze hebten weinig of geen structuur en ze zijin dan ook wiskundig handelbatar. Eerste-orde systemen zijn tot lagen beperkt, waarbij de verbindingen alleen binnen de lagen en tussen aan elkaar grenzende lagen toegestaan zijn. De Hopfield en Kohonen metwerken zijn nulde-orde-systemen, en als zodanig geen goede benadering van het brein waarvoor ze ook niet bedoeld waren. Perceptrons zijn net als de back propagation-netwerken met huin verborgen lagen, eerste onde, gelaagde netwerken.

Als er bininen een laag nog een structuur wordt aangebracht, waardoor wederom het totaal auntal tussenverbindingen afneent, hebben we te maken met een tweede-orde-systeem. Zo'n tweede-orde-systeem is bijvoorbeeld het woondherkenningsmodell van McClelland en Rumelhart en het Selective Attention Model (SLAM) ${ }^{23}$ voor visuele aandacht. Deze systemen zijn wonom lastig om analytisch uit te pluizen, en onderzoekers hebben dan ook hun toevlucht moeten zoeken tot simulatiestudies. Wat deze modellen anders maakt is dat de combinatie van zowel een horizontale gelaagde structuur als een vertikale struchuar afzonderlike modulen oplevert. Bovendien kunnen deze modulen allemaal tegelijkertijd en onafhankelijk van elkatr berekeningen uitvoeren, en dat is iets wat de lagere-ordesystemen niel kumnen. De derde-orde structuur wordt gekenmerkt door zowel een modulaire structuur als doordat er verschillende soorten neurale verwerkingsmechanismen zijn. Deze kunnen verschillende tijdschalen of andere gedragsdefinities hebben die gen goed inzicht praktsch onmogelijk maken, mar die realistischer zijn als benadering wan de werkelijke verscheidenheid van hersenstruktunen. Naar mijn mening is de tweede orde woereikend voor vandaag en de nabije toekonst.

\section{De Amanomie van de Hersenen, Hersenkwabben, Gebieden en "Minicolumns"}

Wanneer we naar de hersenen kijken, blijkt dat ze zijn opgebouwd wit vele netwerken, op hun beurt weer gevat in andere, grotere, netwerken. Op ell niveas zijn er op zichzelf 
stuande gedeelten, modules. Deze modules ziju van bimnen rijk roorzien van werbindingen, terwijl de verbindingen voor in- en üwoer met andere modules beperkt zijn. Dit lijkt dus op de tweede onde benadering van kunstmatige neurale netwerken die ik zojuist besproken heb. Als we de neurofysiologen moeten gelowen, heblen deze modules elk zeer specifielke taken en functies. Gnotere modules zijn op hun beurt weer opgebound uit kleinere en op een bepaald niveas kunnen we cen begin maken met ze in verband te brengen met psychologische functies, waarvan verwerken van Natuurlifke Taal er cen is 24 .

De hersenen zijn zeer gestructureerd gebouwd. Br zijn twee hemisfenen met opniew zeer gestructureerde subcorticale structuren. De hersenhelften zijn op hun beurt weer verdeeld in vier kwabben die in een patroon gekreukeld zijn van plooien en groeven. Newrologische onderzoeken op menselijike patiurnten, gecombineerd met diersitudies, hebben structuren voor hoge perceptuele functies alis zien en horen in het achterhoofd en bij de temporele kwab aan het licht gebracht in ieen grote verscheidenheid aan dieren. Tegelijkertijd bleek dat, hoewel de locatie van dergelijke structuren bij veel dieren en mensen ongeveer gelijk is, nauwkeurige bestudering van deze structuren verschillen laten zien in de fijne opbouw, de zogenaamde "cytoanchitectuur'. Het meest bekende voorbeeld is waarschijnlijk Brodmann's kaar van de hersenen. Hij liet zien dat bepaalde delen van de hersenen verbonden waren met onze zintuigen en de organen die reflexmatige bewegingen beheersen. Dit kan woorspeld worden wit de manier warop de verbindingen lopen. Als we het spoor terug volgen vanaf de ogen of in het algemeen vanaf het ruggemerg komen we uit op gebieden die we kunnen relateren an onmiddellijke zintuiglijke analyse en de beheersing wan bewegingen. De volgende wraag is nu, wat deze informatie bijdraagt aan de kennis over perceptie en beheersing van bewegingen als rekentechnische problemen. Hoe voert het zenuwweetsel de berekeningen daadwerkelijk uit? Wat wordt er eigelijk berekend? Welke neuro-anatomische en neuro-fysiologische gegevens zijn er van belang?

Het is natuurlijk mogelijk dat het brein als het eenmaal de primaire ruwe data heeft xijn berekeningen dusdanig organiseert dat het op geen enkele manier meer doet denken ann de grove neuroanatomie. Frenologen zoals Franz Joseph Gall raakten in diskrediet ondat ze voorstelden dat het menselijk kunnen weerspiegeld werd door de achitectuur van het brein en elke waardigheid gelokaliseerd kon worden in hobbels, bobbels en richels op de schedel25. Hij ging misschien dan ook wat te ver met zijn schedelmetingen, het meten van bijvoorbeeld de intellectuele capaciteit of goed moederschap aan schedelknobbels. Toch tonen anderzijds studies van de effecten van plaatselijk hersenletsel samen met technieken zoals prikkeling van de oppervlakte wan het hersenschors atan, dat schade in specifieke kleine gebieden wel degelijk geassocieerd kunnen worden met specifieke functionele stoomissen.

Een van de interessantste vondsten, die van grote invloed is geweest, is de zogenaamde 'minicolumn'. Mountcastle 26 ontdekte dat de hersenschors is opgebouwd uit een groot Hantal kleine modules die in vertikale kolommen natast elkaar liggen. De hersenschors is een dunne sehil van slechts enkele millimeters dik, waarin zes lagen kunnen worden onderscheiden. De "minicolumns" kunnen gezien worden als een beperki gebied van onderling verbonden hersencellen in een beperkte locatie over de zes lagen. De verbindingen lopen voomamelijk van boven naar beneden en de verbindingen met andere minicolumns" zijn beperkt tot enkele lange vezels die of uit de boven of uit de onderkant van de kolom komen. De minicolumns kunnen gezien worden als een representatle vain beperkte modules ${ }^{27}$ die gekenmerkt worden door hun hoge interne bedradingsdichtheid in tegenstelling tot de verbindingen mett de andere kollominen. Elk van deze modules kauni specificke berekeningen uitvoeren. Het bewijs hierwoor is op het gebied van het visuele systeem overtuigend geleverd. De gevolgen van deze modulaire opbouw op hogere, perceptuele, niweaus zijn echter nog onduidelijk. Blijft de vraag of andere functies, zoals taal. gebruik maken van een soortgelijke specificiteit als voor het wisuelle systeem geidentificieerd is Misschien liggen deze functies wat meer verspreid, en hebben niet 
zoals ons gezichtsvermogen een nearologische representatie die de buitenwereld werspiegeli als platuegronder op de hersenen 28

\section{Taal en de Hersenen}

Hel bewijs voor een afzonderlike, afgebakende plabts voor talwerwerking in de hersenen is geleverd dow de Franse neuroloog Paul Broca. In 1861 liet hij zien dat verwerking van taal gelocaliseerd is in de voorzijde van de linker hersenkwab 29 . Hij kwam tot deze conclusue na bestudering van de hersenen van een overleden pacient die thjens zijn leven zijn spraakvermogen was kwijtgeraakt. De Duitse neuroloog Wemickejo breidde deze kennis nog verder uit door hef identificeren van gebieden voor de produktie en perceptie van spratak en taal. Hij localiseerde taalproductie in de voorkanit van de linker hersenkwab en perceptie bij de silap van de linker hersenkwab. Hij makke ook een diagram van de taalfuncties, watrin de verbindingen tussen verschillende onderdelen waren aangegewen. Een arival op deze 'Diagram Makers' zoals Wernicke en zijn volgelingen werden genoemd, kwam van de Engelse neuroloog Sir Henry Head 31 . Zijn aanval had en vergelijkbaar effect als de aanval van Minsky en Papent op de Perceptrons. Een meer nauwkeurige lezing van zijn artikel laat echter zien, dat hij niet geheel af wijzend stond tegenover het opstellen van specifieke modellen: hij was alleen tegen het ongebreidelde en ondoordacht gebruik ervan. De meest recente editie van het boek van Minsky en Papert vertoont trouwens eenzelfde nuancering. Het basisprobleem zit in het feit dat we specifieke schade aan de hersenen kunnen relateren aan specifieke symptomen, aan de specifieke taalproblemen die een patiënt heeft. De "Diagram Makers" makkten de grote stap van het gelijkschakelen van de functie wan een gedeelte van de hersenen met de vertoonde symptomen bij prikkeling wan deze gedeelten.

De gevolgen van Head's anval op de "Diagram Makers" bleven voelbaar tot de Amerikanse neuroloog Noman Geschwind aantoonde, dat er anatomische aanwijzingen zijn, dat er cen relatie is tussen de bouw van de hersenen in een bepaald gebied en het gegeven dat daar taalverwerking zou plaatswinden ${ }^{32}$. De linkerkant van de fasciculus arcuis is beduidend groter dan die in de rechter hersemhelft bij de meeste rechtshandigen. Nu men eenmaal wist waarnaar men moest zoeken, leverde dit soort bewijs een groot antal andere anatomische studies op. De volgende doorbraak was ook een gevolg van werk van Geschwind, ditmaal samen met de neuro-anatoom $A 1$ Galaburda, toe ze ook verschillen op het "cytoarchitectuuns-niveau ontdekten in de taalgebieden in de voorkant van de linker hersenkwab ${ }^{33}$. Zij toonden aan dat de fijme structuur van de hersenen verschillend is op de twee gebieden, genaand de pars opercularis and de pars triangularis. De verhouding tussen de aantallen verschillende types hersencellen is in dat kleine gebied afwijkend van de rest van de hersenen. Dit kan aangetoond worden door de cellen met Lipofuscin te kleuren. Dit soort bewijs onderbouwt de stelling dat de modulaire structuur op microscopisch niveau binnen een gebied dat met taal te maken heeft er anders uitziet dan in gebieden daarbuiten. Een probleem hierbij is natuarlijk, dat weten dat ar een verschil is nog niet erg veel inzicht geeft in de wijze waanop taal wordt verwerkt in de thersenen. Het lijki duidelijk, dat niet alleen hel gezichtsvermogen maar ook taall op een bepaalde plek gelokaliseerd is in de hersenen en dat er bewijs is dat er specifieke verschillen dijn op microscopisch nivead, warschijnijk op "minicoiumn'nivenu.

Wat een mogelijklieid lijkt, maar wat op grond van ons huidig inzicht nog niet bewezen kan worden, is dat de geobserveende verschillen gerelateend zijn an het feit dat de architecturu die in deze gebieden atangetroffen wordt taalspecifrek is. Het bewijs welkt de Indruk dat juist toalproduktie en het verwerken van grammaticale informatie uitgevoerd worden in deze anatomisch te onderscheiden gebieden. De argumenten voor een systeem met de rekenkundige krachi van tenminste een Push. Down Automaton wekken de indruk dat, als we deze systemen samenvoegen, het deze kracht net zou kunen leveren. De af wezigheid van de syntactische vardigheden bij andere diersoorten, en mogelijkerwijs 
ook in de andere hersenhelf laat doonschemeren, dat deze bedrading heel uniel is. Maar er is cen andere voorzichtige conchusie die we kutnen treklken ${ }_{4}$ en dat is dat de specifieke atand van de noodzakelijke rekenkundige kracht die geimplementeend is enig lichil werpt. Toch is dit inzicht nier volledig. De vraag blift wasrom taal is wat deze is, vooral op het niveaiu van de syntaxis.

\section{Het Localiteits- en Modularititits-principe}

Het lijkt erop dat hersencellen het localiteitsprincipe wolgen. Dat betekent dat ieder verwerkend element uitsluitend wondt beĭnvloed door zijn input ${ }^{34}$, De verwerkingskracht en functie is een afgeleide van de manier waarop de neuronen binnen een module, zoals: de 'minicolumns' in de hersenschors, met elkaar verbonden zijn en de manier warop deze modules op hun beurt weer onderling verbonden zijn. Dit betekent dat het geen zin heeft om alleen nar een enkele zenuwcel of kunstmatige knoop te kijken: de samenstelsels en hun eigenschappen zijn het onderwerp van onderzoek. Dit is wat ik in het begin aanduidde met architectum. Daarnaast moeten we het in essentie "eindige staat" karakter van een localle verwerkingseenheid in overeenstemming brengen met minimale vereiste vermogens voor natuurlijke taal. Een eenvoudige opbouw kan nooit aan deze eis voldoen. Bewijzen dat ze zo'n eis wel kunnen benaderen, zijn niet hetzelfde ${ }^{35}$ omdat ze nog steeds in tegenspraak zijn met de principiele beperkingen zoals hierboven weergegeven Het lijkt alsof we de eisen voor een taalverwerker niet in overeenstemming kunnen brengen met het materiaal warin deze geimplementeend is.

Toch is niet alles verloren. Naast het localiteits-principe moet ook het modulariteitsprincipe in ogenschouw genomen worden. $\mathrm{Zij}$ moeten gezien worden als elkat aanvullend, complementair. Een module kan een eenvoudig taak uitvoeren die, hoewel beperkt, een noodzakelijke bouwsteen kan blijken voor een hogere taak. Het bewijs hiervoor is vrij eenvoudig te leveren. De digitale computer is opgebouwd uit dergelijke "finite state ${ }^{k}$-elementen die, op hun laagste niveau zoals logische schakelingen en poorten, gebaseerd zijn op het werk van McCulloch en Pitts. Het bouwen van zulke elementen met neurale netwerken gaat terug tot Hebb en is vrif eenvoudig, zeker als men het idee opgeeft dat het geheugen uitsluitend aanwezig is in de vorm van de gewichten. Hebb introduceerde het idee van de echoende schakeling, mogelijkerwijs zonder enige verplichting om de gewichten aan te passen voor een geheugenrepresentatie. Zo kunnen we dus een patroon tijdelijk opslaan zonder dat we zijn identiteit kwijtraken, doordat het herkenbaar blijtt tussen alle andere eerder opgeslagen patronen. We kunnen dit zelfde eenvoudige principe toepassen op een andere benadering van de wiskunde van berekening: "General Recursive Function Theory"36. In deze benadering is er een module, kunstmatig of natuurlijk, die een bepaalde functie doorrekent, zoals bijvoorbeeld de bepaling, van de maximale waarde van de inputs, beslissen of er een rand zit aan een bepaalde plaats op het netvlies of zelfs beslissen of een gezicht al eens eerder gezien is. Dit zijn taken die Kohonen's netwerk kan uitvoeren. De complexere functies kunnen opgebouwd worden uit georganiseerde verzamelingen wan eenvoudiger structuren.

Op deze wijze kan men computerprogramma's opvatten als programma's die grote functies berekenen. werwijll ze opgebouwd zijn uit georganiseerde verzamelingen van simpeler functies. Maar General Recursive Function Theory levert ook een methode om inzicht te krijgen in de wijxe warop de kleine modules in de hersenen uiteindelijk mogelijk de grote, psychollogische, functies kunnen witvoeren. Het versehil met conventionele computers is echter, dat de hersenen een parallel werkende machine is. Conventionele digitale computers daarentegen werken serieel, dat wil zeggen een taak na de andere afwerkend. Parallellisme, het gebruik wan vele verwerkingseenheden tegelijkertijd, wordt eigenlijk vitsluitend toegepast om gelijksoortige en zich telkens herthalende berekeningen op te splitsen naar de verschillende eenhedien. Bovendien zijn de meeste computers niet in stat om meer dan een taak tegelijkertijd wil te voeren. Zij doen eigenlijk maar net alsof ze een dergelijke onafhankelijkheid bezitten door het gebruiken 
van handige trucs of hoge verwerkingssneheid, of ze hebben eem hoge mate van georganiseed samerispel nodig, wat wet hetrelfide is als echte onafhankelijkheid.

In tegenstelling tot de digitale computers kuniten de hersenen een groot aamtal taken tegelijkertijd uitwoeren. Hoewel er ook woor de mens een greng is aan het aantal taken dat hij of zij tegelijkertijd kan uirvoeten, geldi dit alleen woor taken op een hoog bewustzijns niveau. Terwill we praten, denken en beslissen, gan we gewoon door met ademhalen, wandelen, merken wie obstakels op onze weg op en weten deze ook nog te ontwijken. Elk van deze taken zou zelfs' s werelds krachigste computers zeer zwarar belasten. Toch voeren de hersenen al deze taken tegelijk schijnbaar moeiteloos uit. De zalkenman die zijn auto bestumirt terwijl hij ondertussen een overcenkomst over zijn autotelefoon afsluit, zall hilerdoor de kans op een ongeval enigszins vergroten. Toch het zal niet eenvoudig zijin en gecompliceerde experimenten vergen ${ }^{37}$ om enige vermindering wan de nijkwaliteit ook aan te tonen. Dieze prestatie is op zich al verbazingwekkend genoeg, maar de mens heeft bovendien de interessante eigeaschap dat hij heell goed is in het vinden van antwoorden op wragen die, rekentechnisch gezien, erg moeilijk zijn. Problemen als dat van de handelsreiziger of de beoordeling van een situatie zijn erg moeilijk. Vieel van die problemen behoren tot een verzumeling bekend als Non-Deteministic Polynomial (NP) en deze zijn 20 goed als onhandelbaar. De Kunstmatige Intelligentie wordi met veel van dit soort problemen geconfronteerd en KI wordt vaak gebruikt om dergelijke problemen met behulp van reeds an wezige kennis toch op te lossen. Die kennis moet dan helpen de exponentiele groei van de complexiteit en mogelijkheden te beperken als een probleem groter wordt, Het zijn dit soort problemen waar neurale netwerken vaak zeer goede oplossingen kunnen bieden, hoewel nooit gegarandeerd kan worden, dat deze oplossingen ook werkelijk de beste zijn. Veel wan de problemen die we graag en binnen een redelijke tijdspanne zouden willen oplossen, behoren tot de verzameling van NP. De huidige stat van hardware- en sofiware-techniek schiet hier nu nog te kork. Een eigenschap wan de neurale netwerken, dat ze net als de hersenen vrij snel kunnen komen met een redelijke oplossing, biedt echter nieurwe mogelijkheden. In het laatste gedeelte van mijn lezing zal ik zoals beloofd de verschillende standpunten zo goed mogelijk aan elkatar koppelen door enkele ontwerpen voor Zesde Generatie-computers de revue te llaten passeren. Deze Zesde Gereratie moet en neurocomputer worden, in staat thot al die taken waar we het in het begin over gehad hebben, waarbij deze nieuwe generatie een natuurlijke opvoiger is van de vijfde. De Vijfde Generatie was een eerdere poging om tot de bouw van een symbolische kunstanatige intelligentie-computer te komen.

\section{De Zesde Generatie}

Het neemt veel tijd in beslag een meuraal netwerk te laten lopen. Veel van de netwerken zijn in werkelijkheid simulaties die veel computercapaciteit vergen. Zij zjon daarom geknipt om te werken op de moderne supercomputers. Het heren via "Back-propagation' met een redelijk grote set gegevens vreet computertijd op eem ongekende schaal. Alternatieve benaderingen richtten zich op het bouwen van zeer gespecialiseerde hardware, die slechts een zeer beperkt aantal taken kon witwoeren, zoals het per iteratie optellen van het produkt van alle inputs met hun gewichien voor iedere knoop af zonderlijk. Toch makkt de benodigde rekenkracht neurale netwerken wan enige omwang ongeschikt woor praktische toepassingen. Een Cray supercomputer ligt niet in leders berik. De meeste parallelle computers bieden slechts een beperkte hoeveelheid extra verwerkingseenheden. De "Connection Machine" met zijin 65.536 verwerkingsembedlen ${ }^{38}$ is een uitzondering, maar ook hij kent zijn beperkingen waar het gutat on neurale netwerken.

\$telt u zich een Hopfield-Tank netwerk voor, cen twee-dimensionaal netwerk wararbij elke knoop met alle anderen verbonden is. Als er 10 elementen interessant zijn om te bekijken, zoals bijvoorbeeld steden of stappen in een fabricageproces, dan moeten deze paarsgewigg genomen worden, wat 100 knooppunten impliceert. We hebben dan dus 10.000 verbindingen nodig. Als er 100 elementen interessant zijn moeten er al 10,000 
knooppunten en 100.000.000 verbindingen doorgerekend worden. Dit ontstijgt de capaciteit van de huidige 'Connection Machine' aanzienlijk: iedere werwerkingseenheid zou dan 1.500 verbindingen moeten representeren. Als we dergelijke berekeningen met de daarop toegespitste hardware, een neurocomputer, willen uitwoeren moet deze machine $z o^{\prime} n$ volledige onderlinge verbondenheid aankunnen. Wat bovendien de zagk niet rooskleuriger maakt, is de wetenschap dat de Hopfield-Tank netwerk slechts een enkele rekenkundige functie kan doorrekenen, zij het een gecompliceerde. We hebben weinig van de overige voordelen die geassocieend worden met levensechte neurale nerwerken. Ik voorzie dan ook dat zalke twee-dimensionale netwerken niet het overheersende paradigma van de toekomst zullen worden, ondanks het feit dat analyse van dit soort netwerken voor wiskundigen begrijpelijk is. Dit betekent dat hoewel we deze nerwerken kunnen begrijpen zonder dat we ze ook daadwerkelijk kunnen simuleren, dit niet automatisch inhoudt, dat het daarom de meest nuttige of interessante netwerken zijn. Natuurlijk kunnen ze bepaalde taken uitvoeren en kunnen hun nut hebben als onderdeel van een meer complex en heterogeen systeem. Als dit soort systeem niet ideal is, welke zijn dat dan wel?

Een veelbelovende benadering voor een ontwerp is dat er een systeem genomen wordt waarvan reeds bewezen is dat het werkt, en dit dan nagebouwd wordi. Voor neurale netwerken zijn de hersenen niet de geschiktste modellen; sinds McCulloch en Pitts in 1943 proberen we deze al na te bouwen. Er zijn echter wel andere scorten hersenen die we kunnen gebruiken. Het menselijk brein, wat voor een fantastisch rekenwonder het dan ook moge zijn, kan onderzoekers, ontmoedigen door zijn omvang en complexiteit. Sommige onderzoekers prefereren daarom zenuwstelsels die ze in hun geheel kunnen overzien, zoals dat van wormen en eenvoudige slakken als de Aplysia om te kijken hoe deze nu werken. Gewapend met deze kennis probeert men dan dit succesvolle ontwerp van moeder natuur na te bootsen. Zulke benaderingen leiden tot onderzoek van kakkerlakken die, hoewel mischien op de lange duur wel eens succesvoller zonden kunnen zijn dan de mens, toch niet de meest flexibele beesten zijn. Daarnaast betwijfel ik of zij een goede basis vormen voor de bouw van machines die werkelijke kunstmatige intelligentie bezitten. Meer ter zake doende is het probleem dat kakkerlakken geen goede modellen zijn voor grotere systemen: eenvoudige schaalvergroting werkt niet. Dit probleem van de schaalvergroting is het grootste problemen waar een architectuur mee moet kunnen orngaan en zoals u zich herinnert, was dit het probleem dat door Minsky en Papert gesignaleerd werd bij de oudere neurale netwerken.

De kennis die we al hebben over het menselijk brein is nuttig en moet ook gebruikt worden. Daarin is samengebracht alle kennis die we hebben over de neuro-anatomie en neuro-fysiologie van andere, lagere soorten. Door onderzoek wan neurologen en neuropsychologen in de afgelopen eeuw hebben we ook meer inzicht gekregen in de wijze waarop bepaalde functies zijn geïntegreerd. Er is zowel het localiteits- als het modulariteits-beginsel. Ik heb al beargumenteerd dat we deze beginselen kunnen vatten in een rekenkundig model, de recursief functioneel benadering, en tegelijkertijd kunnen we alle wruchten plukken van wat Dan Hillis, de ontwerper van de 'Connection Machine' het 'Ferocious Parallelism' doopte. De snelheid en werwerkingskracht van de menselijke hersenen komt niet van de snelheid en thet vermogen van de afzonderlijke cellen, die erg langzaam werken, maar van de grote hoeveelheid cellen, en de manier waarop ze zijn gegroepeerd. Natuur springt kwistig om met het aantal verwerkingseenheden. Wat we werkelijk willen leren, is hoe we de rekenkracht van al deze afzonderlijke cenheden kunnen kanaliseren. Ik ben van mening dat dit niet kan gebeuren door al deze verwerkingseenheden gewoon op een hoop te goolen. Dit is, hoewel wiskundig zeer inzichtelijk, een zeer inefficiënte oplossing. Het vermogen om zeer nauwkeurige analytische uitspraken te doen ower een neuraal netwerk is gewoonlijk een criterium voor het antwoord op de vraag of een bepaald netwerk wanuit wetenschappelijk oogpunt al dan niet interessant is. KNeine netwerken zij̃ in dit opzicht all lang niet interessant meer. Grotere of meer heterogene netwerken zijn aan de andere kant weer wel interessant, maar het is bijna onmogelijk om daarover gedetailteerde uitspraken te doen. Waarschijnijik is simuleren de enige manier oun lets zinnigs te zeggen over de werking van dit soort 
newerken ${ }^{39}$. Daamatiat moten we dergelike systemen als zo complex beschowwen, dat er nieuwe, soon wan psychologische, theoriebia opgesield moeten worden onite begrijpen hoe ze werken. Inzicht in deze materie zal ons zeker helpen een aanul misvattingen over de paychologie uit de weg he ruimen. Soms hebben we het gevoel dalt een van de redenen warom we biologische wezens niel ech komen begrijpen is, dat we te niet kunnen zien operenen. Het werken met gecampliceerde multi-processor systemen laat zien dat het zien wall de werking niet noodzalkelijkerwijs impliceent dat we ook begrijpen wat ter gebeurt. Zien hoe een goochelaar zijn kunstjes uitvoert, desnoods met behulp van geavanceerde opname-apparatuur, geeft niet noodzakelijkerwijs inzicht in antwoond op de vratg hoe hij dergellijke tnocs doet. Of we op basis van deze inzichten dergelijke kunstjes zelf zouden kunnen leren uitvoeren is vervolgens ook nog maair de vraag.

Wat kunnen wij lleren van de manier waanop de hersenen zowel niet-symbolische en complexe symbolische informatie kan verwerken? Er zijn een groot aantal onderscheiden delen, modules, die slechts beperkt met ellkaar interacteren. De kracht zit hem in het grote anatal en niet in die hoge verwerkingssnelheid van elke individuele cel. De berekenigen die door de hersenen worden witgevoerd kunnen gezien worden als opgelegd aan een lager, voortdurend er parallel verwerkend systeem. Om in te zien wal dil kan betekenen voot de bouw van een Zesde Generatie computer is het goed om in te zien dat deze ontwerpoverwegingen in scherpe tegenstelling staan to wat technici willen bouwen.

We kunnen twee algemene trends onderscheiden 41 . De eerste is de conventionelle extrapolatie van de huidige technologic, die we de naam niet-hersenen-ontwerp kunnen meegeven. De andere is de 'reverse' ontworpen of het hersenen-ontwerp. Het niethersenen-ontwerp is in de grond van de zaak een voortborduren op de huidige technologie, werveelvuldigd on het parallel te maken. Dit houdt in dat men nog steeds probeert on verwerkingseenheden te bouwen die snel werken en die tamelijk gecompliceerd zijn. Hun communicatiesysteem is gericht op verbindingen met alle andere verwerkingseemheden. Zo'n systeem heefit als doel voor ogen het leveren van een algemene implementatie van welk soort netwerk dan ook. Noodzakelijk hiervoor is een potentieel hoge mate van onderlinge verbondemheid. De consequentie daarvan is dat het grootste deel van de relkenkundige inspanning gewijd zal worden wan de ondersteuning van het eigenlijke verbindingspatroon, terwijl de individuele berekening wan de nieuwe output van een knoop door een heel krachtige verwerkingseentheid gedaan zal worden. Het criterium van die grotere schal toepassend kunnen we ons voorstellen dat de eisen voor communicatie groeien mel het kwadraat van het aantal knooppuriten. Met een miljoen knopen zilten we met een gigantisch geheugen waar we mee om moeten gaan. Nu is dit warschijnlijk nog well haalbaar, maar het is nog maar de vraag of dit nu zo'n zinvolle benadering wan het probleem is. De technologie zal tot ongekende hoogten opgestuwd moeten worden, misschien gebruilk makend van optische communicatietechnologit ${ }^{42}$.

De modulaire benadering staat centraal in het ontwerp wan de Zesde Generatie hersenenstijl-computiers. De wetenschap dat het echte brein doordrongen is van modulaite structuren, wan het latagste mini-colomnair nivetu tot eer niweau zo complex als dat van do Nahurlijke Taal geeft aan dat dit een goed principe is. Het complementair principe van localiteit en modulariteit levert bowendien een methode om algemene rekenkundige kracht te hebben zonder extra kracht te hoeven toe te kennen aan individuele verwerkingselementen, zoals de hersencel of de kunstmatige verbindingsknoop. De wijze watop de hersenen hun berekeningen uitvoeren, de algoritmen en hun gedetaillicerde implementaties suggereert bovendien, dat we in stant zouden zijn on een aantal tot nu toe onbegrepen onderdelen van het proces van cognitief verwerken te verklanen. Waarom het is zouls het is en niel anders. We kumnen hierbij verwijzen naar de soorten verwerkingsberekeningen die voor hersenen-stij-computers gemakkelijk zijn uit te voeren. Newell's Playsical Symbol Hypothesis vereist dat elke mentale capaciteit implementabel is op elke willekeurige 'General Purpose Machine", maar legt niet vast war deze implementaties relatief genakkelijker of moeilijker zijn uit te voeren. 
Samenvattend, als psycholoog woel ik dat het begrijpen van hersenen-stijl verwerking; vooral dat van symbolische processen, belangrike nieuwe wetenschappelijke inzichtem zal opleveren, zo lang we maar nitet to dogmatisch zijn.

De benadering waarin de hersenen model staan voor een computer is, an de andene kant, een veel meer ontspannen benadering. We weten dat de hersenen hun flitsend wetk verrichten met behulp van langame verwerkingseenheden en cen onderling verbindingsschema dat voor het grootste gedeelte pllatselijk werkt als gewolg van de modulaire structuner. Dit leidt tot de conclusie dat $20^{\prime \prime} \mathrm{n}$ invalshoek een anzienlijke hoeveetheid rekenkundige kracht kan leveren zonder dat het de risico's heeft die de nivethersenen benadering met zich meebrengen. Ook hier zijn ter wel enkele technologische problemen, maar het schijnt mij toe dat vele hiervan al dicht in de bust van een oplossing zijn. Dit allgemene idee van een modulair systeem dat de hersenen beschrijf op het nivean van tenminste een tweede-orde-benadering niveau, is opvallend consistent met de conclusie van Minsky en Papert, zoals die gewonden kan worden in thun therziente uitgave van Perceptrons. Ze beschrijuen en modulaire, woornamelijk onathankelijke architectuur waarin veel afzonderlijke architecturen samenwerken zoals een samenleving die een gezamenlijk doel voor ogen staat. Ik waag het hier te suggeren dat de hersenen-stijl opbouw van computers, met vele miljoenen jaren van evolutiongire ontwikkeling achter de rug, het op de lange termijn zal winnen, zelfs al zullen we het witeindelijk in een geheel andere technologische vorm geven.

\section{Dames en heren leden wan hei Bestwur der Sriching Wetenschappelijk Onderwijs Limburg.}

Graag spreek ik mijn erkentelijkheid uit woor het door $U$ aan mij geschonken vertrouwen dat blijkt uit Uw besluit mij hier te benoemen. Uw vertrouwen geldt zowel voor mil als persoon, een vreemde eend in de bijt, als voor mijn leeropdrachit, die al net zo ongebruikelijk is. Ik hoop dat met deze leerstoel de combinatie van Taalkunde en Infomatica begrijpelijker wordt en dat ik $\mathrm{kan}$ laten zien dat de te Twee Culturen samen gebracht kunnen worden.

\section{Mijhe heren leden van het College van Bestuur,}

Geache Leden van de Universiteitsrand,

Het is mij een genoegen om in Uw midden plaats te mogen nemen. Hopelijk zult U de verdere uitbouw van deze wrij jonge universiteit in richtingen watarin Nederland sterk is, zoalls Taal en Informatica, zien te verwezenlijken.

\section{Dames en herem van de Faculteit der Algemene Wetenschappen.}

Een Faculteit der Algemene Wetenschappen kan een zeer algemeen karakter hebben, waarin elke vorm van samenhang ontbreekt. Mijn benoeming gls Hoogleraar Taalkunde is, desalniettemin, niet binnen het meer geletterde gedeelte, maar binnen het 'harde'. Ik spreek hier mijn verwachting uil dat de toekomst meer van soortgelijk onverwachte matar logische sprongen de lewendigheid wan deze faculteit zal anntonen.

Dimes en heren van de Vakgroep Informatica,

Na meer dan een jaar un. Uw midden gewerkt te hebben ben ik u zeer erkentellijk voor die voortwarendheid waarmee $U$ zich an mijn lomst heeft aangepast. Als $U$ er niet was geweest, was ik hier nu net geweest. Het is bijzonder prettig om in deze onderzokkstijke omgeving te werken.

Hooggeleerde van den Herik, beste Jaap,

Wij kennen elkaar al langer, maar deze mogelijkheid om tor verder samenwerking is voor mij bijzonder plezierig. Ik hoop dat het zo verder zal ga an en dab wij samen, wroeg in de morgen rijdend, nieuwe hindermissen kunnen owerwinnen en nog meer kennis kunnen vergairen. Of een zesde generatie computer ooil wereldkampioen schaken zal worden us een vraag warover wij ons samen bezig kunnen houden tot in het volgende millenium: 
Hooggeleerde Levelt, beste Pim,

Er zijn weinig mensen die zoveel weten over menselijk taal en psycholinguistische processen als jij. De owerlap tussen tal en neurale netwerken is zeer klein. It heb veel van je geleerd en hoop dat onze discussies over taal en neurale netwerken nog lange tijd vruchuen zullen afwerpeni.

Hooggeleerde Tervoart, beste Ben,

Toen ik yoor het eerste naar Nederland kwam wist ik niet hoe ver ik het zou brengen, het is 230 kilometer geworden en nog wel fn de goede richning cok. Jouw belangstelling voor thal en je persoonlijke danmoediging zijn nog steeds merkbaar in mijn betoog.

\section{Hooggeleerde Wagenaar, Beste Willem-Albert,}

Onze samenwerking be gint zo langzamerhard een waste vorm te krijgen. Jij heb mij altijd vrij gelaten en de ruimte gegeven om mijn interesses te ontwikkelen. Zonder jou was ik miet in de gelegenheid geweest om mijn belangstelling voor de informatica te combineren met psycholinguitstiek, en dai in het gemeenschappelijke kader wan industreile weiligheid watin de theorieen kunnen worden toegepast.

\section{Dames en Heren Studenten.}

De universiteit is een plaats waar het nog steeds mogelijk is om het onverwachte te bestuderen en het onverkende te ontdekken. De wetenschap bouwt voort op zowel het diepgaand bestuderen van én onderwerp als op het volgen van de wijze waarmee verschillende disciplines met elkaar in wisselwerking treden om nieuwe inzichten op te leveren. Van alle Nederlandse universiteiten is Limburg de meeste geschikte om problemen interdisciplinair an te pakken, al betekent dat dat er tenminste twee keer zo hard gestudeerd moet worden om de diepgang in twee richtingen te halen die nodig is om de kwalliteit te handhaven.

Lieve Kate, Christopher, Peter, Timathy en Sarah,

Op deze plaats wil ik jullie hartelijk bedanken voor alle steun en hulp die ik van jullie heb mogen ontvangen en het geduld met mij dat jullie hebben opgebracht. Veel ben ik van huis, met paspoort en al, maar gelukkig is het tegenwoordig vaak to dat ik dit reisdocument alleen nodig heb om hier op kantoor te komen. lk hoop dat jullie in de toekomst mede de vruchten van deze benoeming mogen plakken. 
De auteur bedankt J. Groeneweg sr en jr en I.M.E. Cleton voor hun grote en onmistbare hulp bij het vertalen van deze rede en British Airways voor de mogelifkheid deze rede grotendeels in alle rust en zaligheid te kunnen schrijwen in vlucht BA O0R.

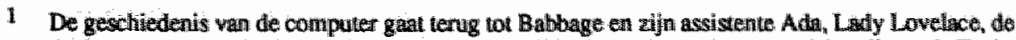
dochter wan de dichter Bym. De practische ontwilkelingen begonnen met wiskundigen als Turing. Post en Church in de fanen 30 en de door de ootlog geinspireente onthwilktellingen in de jaren 40 met wederom Turing en andere als Aiken, Eckert en Mauchly en Von Neaimann.

2 McCulloch. W.S. Fitts, W. (1943) A logical callewlis of the ideas immanent in meural nets. Bulletim of Mathematica Biophysics, $3,115-137$.

3 Hebb, D.O. (1949) The Organizavios of Behaviour. Willey, New York.

4 Lashlay K.S. (1931) Mass action in cerebral function. Science, $73,245-254$; (1950) In search of the engram. Symposium of the Society of Experimental Biology, $4,454,482$.

5 Rosenbtalt, F. (1959) Two theorems of statistical separability in the perceptron. Proceedings of o Sympositum on the Mechanization of Thought Processes. Her Majesty's Stationary Office, London. pp 421-456; Rosenblath, F. (1962) Principles of Neurodymamics. Spartan Books, New York.

6. Zie ook Minsky's eigen proefschrift (1954) Neural nets and the braim model problem. Princeton University, New Jersey.

7 Minsky, M.L. R Paperi, S.A. (1969, 1988) Perceptrons. M.I.T, Press, Cambridge. Massachusutets.

8. Zie ook Lippmann, R.P. (1987) An introductionto computing with neural nets. IEEE ASSP Magazine, April 1987,4-22.

9. Dit wert is een ondendeel van wat leidu tot de moderne complexiteilstheorie. Het is nog steeds verbazingwekkend hoeveel mensen de dagelijkse betekenus van gecompliceerd verwatren met de technische definitie wan complexiteit. Een algoriume kan er bedrieglijk cenwoudig vitzien, maar niat bestand tegen bijivoorbeld schasl vergroting. Geen computer is snel of groot genoeg om de "interessante" varianten van het probleem door te rekenten. Een gecomplicteerd algoritme kan niet be onderscheiden zijn van een eenvoudig als we kijken naar de benodigke hoeveellheid rekentijd of geheugen. Het verkondigen van successen net utsluitend kleine en eenvoudige problemen zou wel cens de ondergang van zowel de kurnstmatige intelligentie als te neurale netwerken zouden kunnen betekenen.

10 Newell, A. \& Simon, H.A. (1972) Human Problem Solving. Prentice Hall, New Jersey.

11 Newell, A. (1980) Physical symbol sysiems. Cogritine Scienci, $4,135 \mathrm{~m} 183$.

12 Morton, 1. (1970) A functional model for memory. In D. Norman (Ed.) Models of Human Memory. Academic Press, New Yort.

13 Lindsay, P.H. Noman, D.A. (1972) Human Informution Prosessing, Academic Press, New York.

14 McClelland "J.L. \& Rumethar, D.E. (1981) An interactive-activation model of context effects in letter perception; Part 1: An account of basic findings, Psychological Review, 88, 60-94, :

Rumethart, D.E. \& McClelliand, J.L. (11982) An interactive-actiwalion model of context effects in letter perception: The contextual enhancement effect and some tests and extensions of the modtel. Psychological Review, 89, 60-94.

15 Rumelhart, D.E. \& MeClelland, N.L. Parallel Distribured Processing: Explorations in the Micro structure of Cognition. M.I.T. Press, Cambridige, Massachusetts.

16 Rumethart, D.W. Hinton, G.E W Willians, R.J. (1986) Leaning internal representations by entor

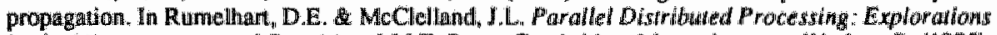
in the Hicro-ginucture of Cognition. M.I.T. Press, Cambridge, Magsachusetts." Wertbos, P. (1975) Beyond Regression: New tools for prediction and anditysis in be havioural sciences. Ph. D. Thesis. Harvard Uniwersity, Harvard Uniwersity, Cambridge, Mussachusells.

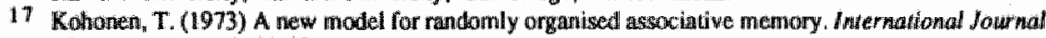
of Newrovitice, 5, 27.29.

18 Hopfield, J.J. (1982) Neural networks and physical systerns with erivergent collect ve computational abilities. Proceedings of the Nationtal Academy of Science USA: Vol 79. Biophysics. 2551.2598.

19 Hopfield, I.J. 2 Tank, D.W. (1986) Computing with neural circuits: A model. Stience "233, 625. 633.

20 Chomsky. A.N. (1957) Symtacric Structures. Mouton, The Hague; (1965) Aspects of the Theory of Symax. M.I.T. Press, Cambritge, Massachusetts.

21 Fodor, J.A. Pylyshyn, Z,W. (1988) Connectionism and cognitive anchitecture: A critical review. Cognition, 28, 3-72. 


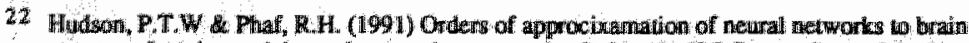

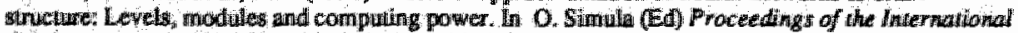
Conference on Arificial Newral Networks - MCAMN91.

23 Phall, R.H. Wain der Heifden, A. Hudson, B.T.W. (1990) SLAM: A coninectionist model for atcention in visual aelection taska. Cognitive Psychology, 22, 273-341.

24 Fouthir, I.A. (1983) The Modularity of Mind. MLIT. Press, Cambridge, Massiachusetus.

29 Hollander, B. (1920) In Search of the Sowl. E.P.Dution, New Yort.

26. Mountcastle, V. (1957) Modality and topographic properties of 3 ingle newrows of cal's somatic sensory contex. Journal of Neurophysialogy, 20, $408434,(1978)$ An organizing principle for cerebral function; the unitmodule and the distributed system. In G.M.Edelnan \& V. B.Mountcasile

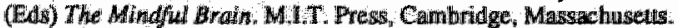

27 Sxentagotual, I. (1975) The Module-concepit in cerebral conex architecture. Rraim Research, 95, 475-496.

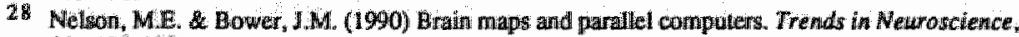
13; $403-408$.

29 Broca, P. (1861) Peirte de la parrole. Ramollisement chronique et difsinction partielie du lobe anterieux ganche du cervetal Bulletin de la Societé d'Anhropologie. 2 .

30 Wernicke, C. (1874) Der Aphasische Symplomemcompilex. Bresilau.

31 Head, H (1926) Aphosits and Kindred Disarders of Speech. Vols 11 \& 2. Cambridge Universicy Press, Climbridge, Hudoon, P.T.W. (1988) Henry Head. In P.Eling (Ed.) From Gall to Geschwind: Histarical Studies in Psycholinguistics. Komer, Amsterdam.

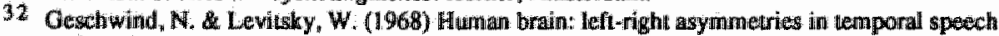
region. Science, 161, 186-187.

33 Gallaburda, A,M., LeMay, M., Kemper, T.L Geschwind, N. (1978) Rightt-left agymmetries in the brain. Scleace, $199,852,856$.

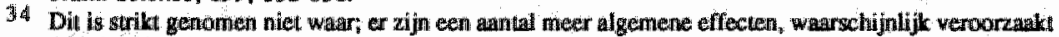
door houmonen die gnote deles van de hersenen kunnen beinvloedten. Dexe effecten zijn evenwel

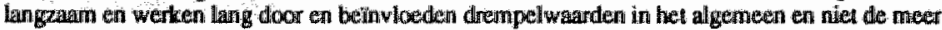
specifteke details van neurale berekeningen.

35 Homik, K, (1991) Approx imation capabilities of mullilayer fecdforward networks. Neural Networks, 4, 251.257, Homil, K, Stincheombe, M. White, H. (1989) Multilayer feedforward networks are universel approximators. Wewrall Nenworks, 2, 359-366; Leveli, W. J.M. (1990) Are multilayer feedforward networks effectively Turing Machines? Psychologücal Research, 52, 153-157.

316 Dawis, M. (1958) Computability and Solvability. Dover, New York.

37 Alterboom, S.P. (1989) Het Begrijpen en Onthouden van Radiowerkeersinfornatie. Proefschrift, R.ULeiden. Werkgroep Veiligheid.

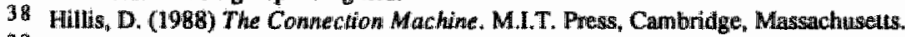

39 Marr, D: (1982) Vusion, A computational investigution ino the human representalion and processing of visual information. Freeman, New York.

40 MITI maps out the Sixth Generation computer. Nature, 345, 279. Japain's quest for the brainy computer: New Sclentist, 26 January, 1991.

41 Treteaven, $\mathrm{P}, \mathrm{C}$. (1990) Neurocomputers. Internatianal Journal of Neturocompiting. 1, 4-31.

42 Frietman, E.E.E., wan Nifterick, W. , Dekker, L. \& Jongeling. T.J.M. (1990) Parallel optical interconnects: Implementation of optoelectronics in multuprocessor architectures. Appplied Optics, 29. 1161.1177 . 